\title{
Partial Nutrient Balances in Tropical Velvet Bean-Maize System in Zimbabwe
}

\author{
Obert Jiri $^{1,2} \&$ Paramu L. Mafongoya ${ }^{1}$ \\ 1 School of Agricultural, Earth and Environmental Sciences, University of KwaZulu-Natal, Scottsville, \\ Pietermaritzburg, South Africa \\ ${ }^{2}$ Agricultural Practice, Faculty of Agriculture, University of Zimbabwe, Harare, Zimbabwe \\ Correspondence: Obert Jiri, School of Agricultural, Earth and Environmental Sciences, University of \\ KwaZulu-Natal, Private Bag X01, Scottsville, Pietermaritzburg 3209, South Africa. E-mail: \\ obertjiri@yahoo.co.uk
}

Received: September 20, 2016

Accepted: November 8, 2016

Online Published: December 15, 2017

doi:10.5539/jas.v10n1p133

URL: https://doi.org/10.5539/jas.v10n1p133

\begin{abstract}
In a field experiment on legume-maize cropping sequence, the effect of nitrogen and phosphate fertiliser application on nutrient budgeting after a two year cropping cycle was studied. The results of this work showed that partial nutrient balances can give an indication about the sustainability of a system unless a full stock of all the nutrients is known. It is also clear from these results that there would unlikely be a carryover of $\mathrm{N}$ to the next season, probably due to leaching of $\mathrm{N}$ from the top soil. Positive partial $\mathrm{P}$ balances would, on the other hand, be of residual value. However, it should be noted that the positive partial $\mathrm{P}$ balances were only observed where maize yield was low. The long-term perspectives of a crop production system cannot be assessed solely on the basis of partial nutrient balances. The nutrient stock: balance ratio may be a better indicator of sustainability, giving a more accurate indication of how long farming can continue in the same way, given the available nutrients. These points towards taking a fresh look at the existing recommended application rates for maize crops.
\end{abstract}

Keywords: residual fertility, maize cropping system, nutrients budgeting

\section{Introduction}

Soil fertility is an important form of renewable natural capital. Plant nutrients in the soil, however, are among the least resilient components of sustainability (Bationo, 2007). The maintenance of soil fertility involves the return to the soil of the nutrients removed from it by harvest, runoff, erosion, leaching, and other loss pathways. The two most widespread limiting nutrients to food production in Africa are N and P, in that order (Khosla et al., 2002). Nutrient capital can be defined as the stocks of $\mathrm{N}$ and $\mathrm{P}$, and other essential elements in the soil, which become available to plant roots in a given period. The nutrient capital can be expressed as $\mathrm{kg} \mathrm{ha}^{-1}$ of $\mathrm{N}$ or $\mathrm{P}$ within the rooting depth of plants.

For rainfed cropping systems in unreliable rainfall regions, there is always the risk that production targets will not be reached. Extremely variable production outcomes can and do influence the decision as to how plant $\mathrm{N}$ and $\mathrm{P}$ supply can be best managed, and a variety of options other than applying fertilizer can be used. Regardless of the risk of $\mathrm{N}$ loss, $\mathrm{N}$ is required by most crops in quantities that are only supplied by fertile soils. The majority of plant $\mathrm{N}$ supplied from the soil is organic which is released through microbial processes into mineral forms (Zingore, 2006).

Mineralization of decomposing crop residues is a major source of plant nutrients in highly weathered soils with low inherent mineral fertility (Sanchez, Buresh, \& Leakey, 1997). In many cropping systems, little or no crop residues are returned to the soil. This leads to a decline in soil organic matter (Lal, 2013), which frequently results in lower crop yields or plant biomass productivity. To achieve better synchrony of soil nutrient release and plant uptake, there is need to be able to predict the outcome of fallow and residue management practices. The benefits of maintaining soil organic matter include the creation of a more productive rooting environment, nutrient retention and storage, and increased buffering capacity in low-activity clay soils (Bargout \& Raizada, 
2013). Some degradation of the soil system through soil organic matter loss results from soil tillage (Dubeux et al., 2015).

Increasingly, farmers in the tropical regions experience production losses due to soil fertility depletion. Although the process of nutrient depletion is generally slow and no abrupt changes in soil fertility occur, the loss of agricultural production can be significant (Lal, 2013). The production of crop outputs and residues is used to calculate total crop nutrient uptake from soils. Nutrient depletion and requirements are assessed by calculating and using estimates of nutrient gains attributable to the application of mineral and organic fertilizers and to biophysical processes of deposition, sedimentation and fixation. Information on weather, soil constraints, soil characteristics and agroecological region is used to estimate soil nutrient losses resulting from erosion, leaching and volatilization (Zingore, 2006). Estimates of nutrient gains and losses are developed from assumed soil nutrient transfer functions and from estimation of empirical statistical models. Empirical nutrient loss models and transfer functions are estimated and used to calculate removal and assess nutrient losses through various mechanisms and processes.

This study analysed $\mathrm{N}$ and $\mathrm{P}$ partial budgets in a weedy fallow, a velvet bean hay crop and a ploughed in or green manure velvet bean system (all followed by maize), using an approach based on nutrient balance or 'book-keeping' (Wijnhoud, Konboon, \& Lefroy, 2003). The resulting nutrient balances are therefore partial balances and basically show what farmers take out of the system and what they add or put back. When the nutrients extracted equal the nutrients applied, the system is assumed to be at equilibrium. Nutrient accumulation occurs when more nutrients are added than removed. A negative balance means that the production system is being degraded as the store of available soil nutrients is depleted.

\section{Materials and Methods}

This experiment was focused on four sites (Mbavha, Mapira A, Gunzvenzve and Dzuna) in Wedza District, Zimbabwe. Two of the sites were sandy soils while the other two were light clays. The soils were generally acidic $\left(\mathrm{pH}_{\mathrm{CaCl}}<5\right)$, inherently infertile (low available $\mathrm{P}, \mathrm{Ca}, \mathrm{Mg}$ and mineral $\mathrm{N}$, total $\mathrm{C}<1.5 \%$ ) sands, loamy sands or light clays at the beginning of the trials (1999/2000 season). Table 1 shows the soil physical and chemical properties at the start of the trial period. The initial soil testing showed generally low concentrations of all the nutrients (Bruce, 1997). There was very low organic carbon in all the sandy soils $(0.2-0.44 \% \mathrm{C})$ and larger but still low concentrations in the heavier soils $(0.89-1.24 \% \mathrm{C})$. The exchangeable cation $(\mathrm{K}, \mathrm{Ca}, \mathrm{Mg})$ concentrations in all the sandy soils were very low (CSRI, undated). Low to moderate exchangeable cation concentrations were recorded in the heavier soils.

Table 1. Soil chemical properties at the different sites before planting in the 1999/2000 season, Dendenyore and Zana, Zimbabwe

\begin{tabular}{|c|c|c|c|c|c|c|c|c|c|c|}
\hline Site & Soil Type & Soil Depth & $\mathrm{pH}$ & $\mathrm{K}$ & $\mathrm{Mg}$ & $\mathrm{Ca}$ & avai. $\mathrm{P}$ & Total N & $\mathrm{C}$ & $\mathrm{C} / \mathrm{N}$ ratio \\
\hline & & ---- cm ---- & & -----" & $\mathrm{mol}_{\mathrm{c}} / \mathrm{k}$ & ----- & $---\mu \mathrm{g} / \mathrm{g}--^{2}$ & |--------- & י-------י- & \\
\hline \multirow[t]{2}{*}{ Mbavha } & \multirow[t]{2}{*}{ Sand } & $0-15$ & 4.28 & 0.12 & 0.06 & 0.32 & 17 & 0.06 & 0.32 & 5.3 \\
\hline & & $15-30$ & 4.02 & 0.06 & 0.03 & 0.12 & 6 & 0.05 & 0.25 & 5 \\
\hline \multirow[t]{2}{*}{ Mapira A } & \multirow[t]{2}{*}{ Sand } & $0-15$ & 4.35 & 0.13 & 0.09 & 0.17 & 8 & 0.05 & 0.44 & 8.8 \\
\hline & & $15-30$ & 4.27 & 0.08 & 0.04 & 0.15 & 3 & 0.04 & 0.28 & 7 \\
\hline \multirow[t]{2}{*}{ Dzuna } & \multirow[t]{2}{*}{ Blackish clay } & $0-15$ & 5.20 & 0.26 & 2.67 & 3.74 & 1 & 0.11 & 1.24 & 11.3 \\
\hline & & $15-30$ & 5.14 & 0.20 & 3.54 & 4.36 & 1 & 0.10 & 1.19 & 11.9 \\
\hline \multirow[t]{2}{*}{ Gunzvenzve } & \multirow[t]{2}{*}{ Red clay } & $0-15$ & 4.42 & 0.20 & 1.69 & 2.89 & 1 & 0.09 & 1.03 & 11.4 \\
\hline & & $15-30$ & 5.22 & 0.12 & 2.70 & 4.78 & 1 & 0.08 & 0.89 & 11.1 \\
\hline
\end{tabular}

Note. ${ }^{1}$ equivalent to meq $/ 100 \mathrm{~g} ;{ }^{2}$ Bray P.

The treatments tested at the four sites are shown in Table 2.

Table 2. List of treatments

\begin{tabular}{ll}
\hline Year 1 treatments & Year 2 treatments \\
\hline Weed fallow & Maize $\left(30 \mathrm{~kg} \mathrm{~N} \mathrm{ha}^{-1}\right.$ applied as AN) \\
Green manure velvet bean with SSP ${ }^{1}$ & Maize $\left(30 \mathrm{kgNha}^{-1}\right.$ applied as AN) \\
Velvet bean hay crop with SSP and lime & Maize $\left(30 \mathrm{kgNha}^{-1}\right.$ applied as AN) \\
\hline${ }^{1}$ Single superphosphate (SSP) contains $9 \% \mathrm{P}, 11 \% \mathrm{~S}, 20 \% \mathrm{Ca}$ and $0.5 \% \mathrm{Mg}$; applied at $200 \mathrm{~kg} / \mathrm{ha}^{2}{ }^{2}$ \\
omitic lime was applied at $500 \mathrm{~kg} / \mathrm{ha}$. &
\end{tabular}


At crop harvesting, the concentrations of $\mathrm{N}$ [determined by the modified Kjeldahl method (Bruce R. Hoskins, 1997)] and $P$ [determined by the ascorbic acid procedure (Bruce R. Hoskins, 1997)] in the biomass were analysed to allow calculation of partial nutrient balances. The partial nutrient balances were then calculated as follows:

$\mathrm{N}$ or P inputs (fertiliser and/or green manure) $-\mathrm{N}$ or $\mathrm{P}$ outputs (hay or grain + stover)

For this study, the green manure input was estimated at $55 \%$ of $\mathrm{N}$ in hay having been derived from fixation (Boddey et al., 2008; Giller, 2001), as biological nitrogen fixation (BNF) characterisation was not carried out for the specific components of this study.

\section{Results}

\subsection{Weed Fallow}

The major weed species included Cynodon spp., Eleusine indica, Cleome monophylla, Richardia scabra, Acanthospermum hispidum, and additionally on the clay sites, Bidenspilosa. The above ground biomass in this system was removed when the velvet bean was harvested (about 130 days after planting) (to simulate grazing by livestock during the dry season). Most of the weeds had flowered and produced seed. The partial nutrient flows for the weed fallow followed by maize system on the different soil types are shown on Table 3 . All the partial $\mathrm{N}$ and $\mathrm{P}$ balances for this system, except partial $\mathrm{N}$ balance at Mbavha sandy soil site in year 2, were negative across all the sites as there was no $\mathrm{P}$ input and the weed biomass was removed. The only $\mathrm{N}$ input in this system was from topdressing N (30 kg/ha) applied in year 2 . The maize crop would have used this up immediately. Dzuna (light clay) site had the most negative year 1 partial $\mathrm{N}$ and $\mathrm{P}$ balances followed by the Mapira $\mathrm{C}$ (sandy loam) and Gunzvenzve (light clay) soil sites. The year 2 partial $\mathrm{N}$ balances were much less negative than the year 1 balances. The Mbavha site had a positive partial $\mathrm{N}$ balance in year 2. This was due to the lower maize yield in year 2 at this site.

\subsection{Green Manure Velvet Bean with SSP}

The partial nutrient balances for the velvet bean green manure - maize system are shown on Table 3 . The green manure velvet bean was incorporated at 130 days after planting in Year 1. The assumption was made that green manure cut in year 1 represented output in year 1. It was then incorporated making it input in year 2. (It is realised that the limitations of this assessment of nutrient balances were that $\mathrm{N}$ fixation was not measured and below ground root biomass was not assessed). The only source of P in year 1 was from SSP (16.4 kg/ha applied to the velvet bean). The year two partial $\mathrm{P}$ balances were all positive, even though there was no $\mathrm{P}$ input in year two. The overall partial $\mathrm{P}$ balances were all positive, indicating the residual effects of $\mathrm{P}$ applied in year 1.

\subsection{Velvet Bean Hay Crop with Lime and SSP}

The partial $\mathrm{N}$ and $\mathrm{P}$ balances for the limed velvet bean (above ground biomass removed) followed by maize system are shown on Table 3. This cropping system had positive overall partial $\mathrm{P}$ balances on sandy soil sites but negative $\mathrm{P}$ balances on clay soil sites. The partial $\mathrm{N}$ balances were all negative. This system had the most negative overall partial $\mathrm{N}$ balances, almost all more than double those of the weedy fallow-maize, at all the sites.

Table 3. Partial $\mathrm{N}$ and $\mathrm{P}$ balances in the weed fallow, velvet bean green manure and limed velvet bean systems at four sites

\begin{tabular}{|c|c|c|c|c|c|c|c|c|c|c|c|c|c|}
\hline \multirow[t]{2}{*}{ System } & \multicolumn{3}{|c|}{$\begin{array}{c}\text { Mbavha } \\
\text { (sandy soil site) }\end{array}$} & \multicolumn{3}{|c|}{$\begin{array}{c}\text { Mapira C } \\
\text { (sandy loam soil site) }\end{array}$} & \multicolumn{3}{|c|}{$\begin{array}{c}\text { Dzuna } \\
\text { (clay soil site) }\end{array}$} & \multicolumn{4}{|c|}{$\begin{array}{l}\text { Gunzvenzve } \\
\text { (clay soil site) }\end{array}$} \\
\hline & Year 1 & Year 2 & Overall & Year 1 & Year 2 & Overall & Year 1 & Year 2 & Overall & Year 1 & Year 2 & Overall & Mean \\
\hline \multicolumn{14}{|l|}{$N$-partial balances $(\mathrm{kg} / \mathrm{ha})$ : } \\
\hline Weed fallow followed by maize & -48.3 & 12.8 & -35.5 & -98.9 & -51.1 & -150.0 & -198.4 & -28.0 & -226.4 & -96.0 & -40.4 & -136.4 & -137.1 \\
\hline $\begin{array}{l}\text { Green manure velvet bean }(+\mathrm{SSP}) \\
\text { followed by maize }\end{array}$ & -248.4 & 174.8 & -73.6 & -268.6 & 201.9 & -66.7 & -209.0 & 132.8 & -76.2 & -483.8 & 345.8 & -138.0 & -88.6 \\
\hline $\begin{array}{l}\text { Velvet bean hay crop with lime and SSP } \\
\text { followed by maize }\end{array}$ & -258.1 & -53.4 & -311.5 & -282.0 & -54.7 & -336.7 & -244.0 & -113.2 & -357.2 & -461.7 & -89.0 & -550.7 & -389.0 \\
\hline \multicolumn{14}{|l|}{$P$ - partial balances $(\mathrm{kg} / \mathrm{ha}):$} \\
\hline Weed fallow followed by maize & -1.8 & -1.1 & -3.0 & -4.3 & -7.2 & -11.5 & -12.4 & -2.8 & -15.2 & -3.8 & -3.2 & -7.1 & -9.2 \\
\hline $\begin{array}{l}\text { Green manure velvet bean }(+\mathrm{SSP}) \\
\text { followed by maize }\end{array}$ & 4.7 & 5.7 & 10.4 & 8.5 & 2.7 & 11.2 & 9.7 & 0.7 & 10.4 & 5.8 & 2.2 & 8.0 & 10.0 \\
\hline $\begin{array}{l}\text { Velvet bean hay crop with lime and SSP } \\
\text { followed by maize }\end{array}$ & 7.5 & -4.0 & 3.5 & 7.0 & -4.8 & 2.2 & 6.6 & -8.4 & -1.8 & 4.4 & -8.5 & -4.0 & 0.0 \\
\hline
\end{tabular}

Note. Overall: CV $(\mathrm{N})=58.1 \%$; S.e.d. $(\mathrm{N})=31.6 ; \mathrm{CV}(\mathrm{P})=55.4 \%$; S.e.d. $(\mathrm{P})=3.1$. 


\section{Discussion}

Leaving land fallow is commonly practiced in the communal areas of Zimbabwe. Communal farmers use it, among other benefits, to rest the fields and to enhance soil fertility. It is also increasingly being used because most smallholder farmers can only afford very little fertilizer which they still apply to the same area and consequently get little return. Table 3 shows a comparison of the partial $\mathrm{N}$ and $\mathrm{P}$ balances in the weed fallow system (usually employed by the farmers) and the introduced velvet bean systems. The results generally show that maize after velvet bean hay (with $\mathrm{P}$ and lime) system was the most unsustainable, having negative partial $\mathrm{N}$ and $\mathrm{P}$ balances ( $\mathrm{N}$ balances on all sites and $\mathrm{P}$ balances on the light clay soils) after the two years, whilst the green manure system was the most sustainable, having less negative partial $\mathrm{N}$ balances (except at Mbavha sandy soil site due to the very low maize yields on the weed fallow at this site in year 2) and all positive partial $\mathrm{P}$ balances.

The partial $\mathrm{N}$ balances for the weed fallow system were mostly negative. This was because there was no $\mathrm{N}$ input in year 1 and all the $\mathrm{N}$ that was applied in year 2 was quickly used by the crop and possibly a significant proportion lost through leaching and other processes. $\mathrm{N}$ losses due to leaching were large (Table 3), and some $\mathrm{N}$ may be lost as gases through volatilization $\left(\mathrm{NH}_{3}\right)$ or denitrification $\left(\mathrm{NO}_{2}\right)$. This could explain the negative balances in this system across the sites. $\mathrm{N}$ source is largely from the soil reserves and the mineral fertilizers (Whitbread, Jiri, \& Maasdorp, 2004). Farmers would have to apply full rate of mineral fertilizer to a crop following a one year grazed weed fallow in order to have positive $\mathrm{N}$ balances in this system. This may still not offset the huge negative partial $\mathrm{N}$ balances at sites such as Mapira C, Dzuna and Gunzvenzve. The full rate inorganic fertiliser $(300 \mathrm{~kg} / \mathrm{ha}$ ) would supply about $120 \mathrm{~kg} \mathrm{~N} / \mathrm{ha}$.

There was no $\mathrm{P}$ input in the weed followed by maize system. The magnitude of negativity could be due to differences in yields at the different sites as mining of $\mathrm{P}$ in the yield.

The green manure velvet bean-maize system had all positive partial $\mathrm{N}$ balances in year 2 but all negative year 1 and overall partial $\mathrm{N}$ balances. There was a huge input of $\mathrm{N}$ from fixation. An average of $55 \%$ of the velvet bean $\mathrm{N}$ was assumed to come from $\mathrm{N}_{2}$-fixation. This could have been an underestimate (Giller, 2001). When a dense canopy develops velvet bean becomes self-shading, so that the leaves lower in the canopy senesce. The fallen leaves may contribute substantial amounts of N (Giller, 2001). Whitbread and Pengelly (2004), for example, showed that in tropical legume pastures grown in central Queensland, $50-70 \%$ of $\mathrm{N}$ in the legume tops was derived from fixation in years 1 and 2 . This decreased to $<13 \%$ in years 3 and 4 of the rotation. Oenema et al. (2003) reported that $\mathrm{N}$-fixation ranged from $20-25 \mathrm{~kg} \mathrm{~N} / \mathrm{t}$ dry matter regardless of species, soil type and environment.

The velvet bean green manure $\mathrm{N}$ that was incorporated in year one, however, did not lead to increased concentration of $\mathrm{N}$ in the maize yields obtained in year two. Where some of the $\mathrm{N}$ goes to and how much of the incorporated $\mathrm{N}$ finds its way into the soil solution remains a matter of speculation, for example the fauna inhabiting the soil may have immobilized $\mathrm{N}$. The turnover of this $\mathrm{N}$ is relatively fast and hence the net release of some of it is possible, even within the maize growing period, still in time for subsequent plant uptake (Shisanya, 2005). The overall partial $P$ balances were positive, indicating a build-up of $P$ reserves in the green manure systems. The green manure system would be more sustainable in terms of $\mathrm{N}$ and $\mathrm{P}$ accumulation compared with the weedy fallow and the velvet been hay systems.

The limed velvet bean hay with $\mathrm{P}$ and lime followed by maize system had the most negative partial $\mathrm{N}$ balances. This was mainly because of the removal of $\mathrm{N}$ and $\mathrm{P}$ in the above ground biomass. Removal of between 60 and $75 \%$ of the above ground biomass would account for substantial removal of fixed $\mathrm{N}$. The bulk of the $\mathrm{N}$ accumulated by the velvet bean should be from $\mathrm{N}$ fixation (Giller, 2001). The huge negative partial $\mathrm{N}$ balances reflect the large amount of $\mathrm{N}$ fixed by velvet bean. There would be substantial amounts of fixed $\mathrm{N}$ in roots and nodules, as well as decomposed litter and leaf fall. Thus the removal of the above ground biomass from the field would not necessarily deplete the soil $\mathrm{N}$ reserves. The assumption was that the velvet bean above ground biomass would be used for cattle feed. The cattle manure might be returned to the field and so these negative partial $\mathrm{N}$ balances might also be partially offset. Thus the negativity of the velvet bean systems is overestimated. Overall $\mathrm{P}$ balances in this system were positive on the sandy soil sites and negative on the light clay soils. This could mean some $\mathrm{P}$ fixation on the clayey soils and higher maize yields at these sites than at the sandy soil sites.

Across the three systems compared in this study, the velvet bean hay crop with lime and SSP proved to be the most unsustainable in terms of the partial $\mathrm{N}$ balances. The overall partial $\mathrm{P}$ balances in the velvet bean hay crop with lime and SSP system were positive on the sandy soil sites and negative on the clay soil sites. Overall, however, a conservative view is that $\mathrm{P}$ availability remains fairly stable in the velvet bean systems despite the yearly exports (via harvests) amounting to about 10-100 $\mathrm{kg} \mathrm{ha}^{-1} \mathrm{year}^{-1}$ depending on the soil type (Sanchez et al., 
1997). The maize following weed fallow system was also unsustainable. The partial $\mathrm{N}$ balances were, however, less negative than in the maize following velvet bean (grown for hay) system. This was largely due to lower yields in the maize following weed fallow system.

Better maize yield tended to influence the negative $\mathrm{P}$ values. The greater the yield, the more $\mathrm{P}$ would be exported in the yield. A poor yield would mean less $\mathrm{P}$ exported in the yield and thus more residual P left for the following crop.

It is important to note that the nutrient balances were calculated for the above ground biomass only. It would be important not to underestimate the contribution of the velvet bean root biomass to $\mathrm{N}$ accumulation. Even where the above-ground biomass of velvet bean has been removed, there may be significant amounts of $\mathrm{N}$ added to the soil in the form of dead roots, nodules and other contributions from rhizodeposition. Recovery of roots of grain legumes has indicated that about $10 \%$ or less of the plant $\mathrm{N}$ is present in roots at harvest (Stocking, 2003). Considerably more $\mathrm{N}$ may be present in the root systems of growing plants (Giller, 2001). The $\mathrm{N}$ in roots and nodules of annual legumes may be translocated to the shoots during senescence, but less than $30 \%$ of the $\mathrm{N}$ in roots is usually remobilised (Giller, 2001).

However, a single negative nutrient balance does not reveal much about the future of the system unless the full stock of all the nutrients is known. There would unlikely be a carryover on $\mathrm{N}$ to the next season due to leaching. Positive partial P balances would, on the other hand, be of residual value. However, it should be noted that the positive partial $\mathrm{P}$ balances were only observed where maize yield was low. Net negative or slightly positive partial $\mathrm{P}$ balances mean that the farmers would need to reapply $\mathrm{P}$ in the next season. The positive $\mathrm{P}$ balances could also be due to $\mathrm{P}$ from sparingly soluble $\mathrm{P}$ pools which may well be an input based on Mucuna root and shoot residues that release P from unavailable to available pools - one of the reasons that Mucuna grows well on nutrient poor soils and is used as a green manure. This may limit applicability of the nutrient budget approach to monitor P.

It would be interesting to determine the effect of a second (and even third) year of maize cropping on the partial $\mathrm{N}$ and $\mathrm{P}$ balances and general systems sustainability.

\section{Conclusion}

The results of this work showed that partial nutrient balances give an indication about the sustainability of a system unless a full stock of all the nutrients is known. It is also clear from these results that there would unlikely be a carryover of $\mathrm{N}$ to the next season, probably due to leaching. Positive partial $\mathrm{P}$ balances would, on the other hand, be of residual value. However, it should be noted that the positive partial P balances were only observed where maize yield was low. The long-term perspectives of a crop production system cannot be assessed solely on the basis of partial nutrient balances. The nutrient stock: balance ratio may be a better indicator of sustainability, giving a more accurate indication of how long farming can continue in the same way, given the available nutrients. Given that BNF is not well characterized for Mucuna, it would be recommended in further studies to help estimation of nutrient balances in Mucuna systems. Further, Mucuna is often grown as a green manure, so stover would not be removed in such cases, it would be necessary to include other scenarios such as $50 \%$ removal or no removal to assist in understanding the nutrient balances in the Mucuna cropping systems. Another gap that would need to be explored is an estimation of the root biomass BNF contribution to nutrient balances.

\section{References}

Bargout, R. N., \& Raizada, M. N. (2013). Soil nutrient management in Haiti, pre-Columbus to the present day: lessons for future agricultural interventions. Agriculture \& Food Security, 2(1), 11. https://doi.org/10.1186/ 2048-7010-2-11

Bationo, A. (2007). Advances in Integrated Soil Fertility Management in Sub-Saharan Africa: Challenges and Opportunities. Springer Science \& Business Media. https://doi.org/10.1007/978-1-4020-5760-1

Boddey, R. M., Jantalia, C. P., Zotarelli, L., Okito, A., Alves, B. J. R., Urquiaga, S., \& Amado, T. J. C. (2008). Nutrient mining on carbon sequestration? BNF inputs can make the difference. Biological Nitrogen Fixation: Towards Poverty Alleviation through Sustainable Agriculture.

Bruce, R. H. (1997). Soil testing handbook for professionals in agriculture, horticulture, nutrient and residuals management. In B. R. Hoskins (Ed.), University of Maine (3rd ed.). Maine Forestry \& Agricultural Experiment Station, University of Maine. https://doi.org/10.1017/CBO9781107415324.004

Dubeux Jr., J. C., Muir, J. P., Nair, P. R., Sollenberger, L. E., Silva, H. M., \& de Mello, A. C. (2015). The advantages and challenges of integrating tree legumes into pastoral systems. Forages in Warm Climates (p. 
141). Retrieved from http://www.neforufla.com.br/upimg/ck/files/Proceedings_CONFOR_2015.pdf\#page $=141$

Giller, K. E. (2001). Nitrogen fixation in tropical cropping systems (2nd ed.). CABI Publishing. https://doi.org/ 10.1079/9780851994178.0000

Khosla, R., Fleming, K., Delgado, J. A., Shaver, T. M., \& Westfall, D. G. (2002). Use of site-specific management zones to improve nitrogen management for precision agriculture. Journal of Soil and Water Conservation, 57(6), 513-518. Retrieved from http://www.jswconline.org/content/57/6/513.abstract

Lal, R. (2013). Food security in a changing climate. Ecohydrology \& Hydrobiology, 13(1), 8-21. https://doi.org/ 10.1016/j.ecohyd.2013.03.006

Oenema, O., Kros, H., \& de Vries, W. (2003). Approaches and uncertainties in nutrient budgets: Implications for nutrient management and environmental policies. European Journal of Agronomy, 20(1-2), 3-16. https://doi.org/10.1016/S1161-0301(03)00067-4

Sanchez, P. A., Buresh, R. J., \& Leakey, R. R. B. (1997). Trees, soils, and food security. Philos Trans R Soc Lond B Biol Sci, 352(1356), 949-961. https://doi.org/10.1098/rstb.1997.0074

Shisanya, C. A. (2005). Economic analysis of maize-tepary bean production using a soil fertility replenishment product (PREP-PAC) in semi-arid Eastern Kenya. Journal of Food, Agriculture \& Environment, 3(2), 208-212.

Stocking, M. A. (2003). Tropical soils and food security: The next 50 years. Science (New York), 302(5649), 1356-1359. https://doi.org/10.1126/science.1088579

Whitbread, A. M., Jiri, O., \& Maasdorp, B. (2004). The effect of managing improved fallows of Mucuna pruriens on maize production and soil carbon and nitrogen dynamics in sub-humid Zimbabwe. Nutrient Cycling in Agroecosystems, 69(1), 59-71. https://doi.org/10.1023/B:FRES.0000025291.62043.11

Whitbread, E. A. M., \& Pengelly, B. C. (2004). Tropical Legumes for Sustainable Farming Systems in Southern Africa and Australia. ACAIR.

Wijnhoud, J. D., Konboon, Y., \& Lefroy, R. D. B. (2003). Nutrient budgets: Sustainability assessment of rainfed lowland rice-based systems in northeast Thailand. Agriculture, Ecosystems and Environment, 100(2-3), 119-127. https://doi.org/10.1016/S0167-8809(03)00180-4

Zingore, S. (2006). Exploring diversity within smallholder farming systems in Zimbabwe. Retrieved from http://edepot.wur.nl/121799

\section{Copyrights}

Copyright for this article is retained by the author(s), with first publication rights granted to the journal.

This is an open-access article distributed under the terms and conditions of the Creative Commons Attribution license (http://creativecommons.org/licenses/by/4.0/). 